\title{
Married to Intolerance: Attitudes towards Intermarriage in Germany, 1900-2006
}

\author{
Nico Voigtländer, Hans-Joachim Voth
}

Marriage is amongst the biggest decisions in life. In general, there is a tendency towards assortative matching - people marry others who are relatively similar to themselves. Intermarriage between different social, religious and ethnic groups in most societies is relatively rare (Blossfeld and Timm 2003). Where it occurs, it is associated with more rapid assimilation (Meng and Gregory 2005). The frequency of intermarriage can therefore serve as a useful indicator of tolerant attitudes towards a minority, and of the desire to integrate (Bisin, Topa, and Verdier 2004).

In this paper, we analyze under which conditions intermarriage can be used as an indicator of tolerance, and whether such tolerant attitudes persisted in Germany during the last century. We combine information on individual-level attitudes from the German social survey (GESIS) with historical data on marriage patterns. In Nazi Germany, marriages between Jews and “Aryans” were considered a major threat to the racial purity of the German people. The strong trend towards more intermarriage between Jews and gentiles that characterized the Weimar years came to an abrupt end after 1933 (Figure 1). The Nuremberg racial laws placed heavy restrictions on intermarriage (Burleigh and Wippermann 1991). The NS regime compiled detailed statistics on the ethnic background of the population, classifying people as “full Jews”, "half Jews”, “quarter Jews”. These records, created by the German authorities after 1933, can be used as a measure of past intermarriage.

\section{[Figure 1 here]}

We examine the extent to which a history of out-marriages in early $20^{\text {th }}$ century Germany predicts attitudes in the same location towards marrying a Jew almost a century later. The German Social Survey (ALLBUS) questioned a representative sample of German respondents in 1996 and 2006 about their attitudes towards Jews. One set of survey question relates to preferences towards 
intermarriage with Jews. German levels of anti-Semitism today are broadly similar to those in other European countries (Gabriel 2000). At the same time, distaste for intermarriage with Jews in modern-day Germany is not low on average, and varies considerably from one location to the next. We exploit this variation to examine if in towns and cities with numerous offspring from "mixed" marriages in the period 1900-1940, modern-day attitudes towards intermarriage are markedly more tolerant.

We find strong evidence for the persistence of tolerant attitudes. However, our empirical analysis also cautions against using intermarriage as a simple proxy for tolerance: The size of Jewish communities in the early $20^{\text {th }}$ century is an important confounding factor. In smaller communities, where in-group matches were difficult to find, intermarriage was more frequent. At the same time, small Jewish communities were typically located in smaller towns with less tolerant attitudes. Therefore, smaller communities show both more intermarriage and less tolerance; raw correlations suggest a negative relationship between intermarriage and tolerance today. To identify the historical tolerance component in intermarriage, we use detailed data on elections for anti-Semitic parties between 1890 and 1912. Where people voted less for the anti-Jewish parties, intermarriage was more common; this component of historical intermarriage shows a positive association with present-day attitudes towards marrying Jews.

\section{Data}

Before 1933, the only consistent source of information on the number of Jews in Germany was compiled by the registry offices, which kept track of the legal residence of everyone living in Germany. Jews were only counted as such if they formally affiliated with the Jewish faith; converts were not considered. The Nazi authorities engaged in a large-scale data collection effort to assess the number of Jews overall, including converts and those of mixed ancestry. This was meant to remedy the problem that the earlier statistics did "not shed light on the invasion of Jewish blood into the body of the Volk.” (Statistisches Reichsamt 1944) The culmination of this effort was a special 
questionnaire, administered as part of the 1939 census, which required all respondents to file detailed information on the race of their grandparents. Those with three or more Jewish grandparents were classified as "Volljuden" (full Jews); those with two Jewish grandparents were "mixed of the first degree", and those with only one Jewish grandparent were classified as "mixed of the second degree" (Burleigh and Wippermann 1991).

According to the 1939 census, there were 442,000 Jews left in Germany; of these, 74.7\% were fully Jewish, $16 \%$ were mixed of first degree, and a little less than $10 \%$ were mixed of second degree. There was substantial heterogeneity at the regional level: in Hesse, only $18 \%$ of all marriages were mixed, whereas in Hamburg, 44\%. Since the beginning of the $20^{\text {th }}$ century, intermarriage had become much more common. Of those who married before 1914 , only $21.5 \%$ of Jews were in a mixed marriage; by 1932, this had surged to 65.1\%. As soon as the Nazis came to power, intermarriage in Germany plummeted. By 1939, only 20.6\% of new marriages involving Jews were mixed, even fewer than before World War I (see Figure 1). To measure historical anti-Semitism, we use the average vote shares for anti-Semitic parties from six nation-wide elections between 1890 and 1912, ASVOTE ${ }^{19 C}{ }^{1}$ In combination, our historical city-level data comprise 759 observations - all cities with Jewish inhabitants in 1939 where anti-Semitic parties had put forward candidates in at least one of the six elections between 1890 and 1912.

We pair this historical data with the large-scale German social surveys (ALLBUS), using the two editions that collect data on attitudes towards Jews - 1996 and 2006. In addition to several other questions (“Do Jews have too much influence in the world?”; “Should Jews have equal rights?”, etc.), the survey also asks how people feel about the possibility of a Jew marrying into their family. On a scale from 1 (very disagreeable) to 7 (very agreeable), respondents are asked about their reactions. The modal response is neutral (4, given by $49 \%$ ). Some $10 \%$ find the idea very disagreeable; $8.4 \%$

\footnotetext{
${ }^{1}$ This dataset is from Ritter and Niehaus (1980).
} 
claim to be very pleased with it. There is substantial variation by region, especially when it comes to extreme responses. In Lower Bavaria, 39\% of respondents find the idea of a Jew marrying into their family either quite or very disagreeable. At the opposite end of the spectrum, in Hamburg, only 5.6\% of people feel this way. Overall, we draw on data from 264 cities with 6,643 individuals.

\section{Results}

We first analyze raw correlations between modern-day attitudes and historical intermarriage rates, and then disentangle the underlying drivers.

Contrary to expectations, German towns and cities where “mixed marriages” were more common before 1939 show less tolerance towards intermarriage today. This basic pattern holds for both attitudes towards marrying a Jew (Table 1, columns 1 and 2) and intermarriage with ethnic minorities in general (columns 3 and 4). This is true if we use offspring with two Jewish grandparents as an indicator of intermarriage (MixedJew $1^{\text {st }}$ ) or if we use all offspring with one or two Jewish grandparents (MixedJew2 ${ }^{\text {nd }}$ ). In the regressions, we control for personal characteristics - age and education - as well as the wave of the survey. The basic correlation is particularly surprising because there is ample evidence that anti-Semitic attitudes in Germany are highly persistent, with medieval patterns of pogroms still having predictive power for behavior 600 years later (Voigtländer and Voth 2012). What can account for such a puzzling result?

\section{[Table 1 here]}

Two factors contribute to intermarriage - the willingness to marry across ethnic lines, and the possibilities for minority members to find a mate inside their own group. The first channel is affected by how tolerant the local German population is towards Jews. Where gentiles were more favorable towards their Jewish neighbors in the past, we expect more intermarriage - and more positive attitudes today. Where this channel operates, intermarriage reflects tolerance towards minorities. The second channel may confound this relationship. Smaller towns are typically less tolerant towards minorities, and they also host smaller Jewish communities. Smaller groups, in turn, have a greater 
need to marry outsiders because suitable inside matches are harder to find (Banerjee et al. 2009). Thus, since smaller Jewish communities were located in less tolerant towns, this channel leads to a negative association between historical intermarriage and present attitudes. In other words, where local attitudes were hostile, and the Jewish community was small, intermarriage rates may have been higher simply because there were not enough feasible matches for individuals of marriable age. ${ }^{2}$ If this second channel dominates, the overall relationship will have the opposite of the expected sign. This can rationalize the results in Table 1.

Larger cities were more tolerant than smaller ones in several ways; in particular, they showed less anti-Semitism at the ballot box. ${ }^{3}$ At the same time, Jews could choose from a large number of co-religionists before having to consider gentiles as a possible match; intermarriage was correspondingly rare (Figure 2). Table 2 shows that out-marriage was particularly common in towns with small Jewish communities; as the number of Jews increased, intermarriage became increasingly rare. ${ }^{4}$ This pattern is true for both types of mixed marriages - those involving (in NS terminology) "full Jews" and "half Jews". At the same time, all regressions suggest that larger cities are more tolerant towards intermarriage (after controlling for the size of Jewish communities). In addition, we find a consistent negative effect of deeply rooted anti-Semitism on intermarriage rates. We use two

\footnotetext{
${ }^{2}$ Even if many inhabitants in a community were anti-Semitic, only one suitable match is required for the formation of a marriage. There are many dimensions in which marriage partners can be "compensated“ (i.e., by finding a much more attractive or prosperous match); this implies that some match should be possible if the willingness to compromise is sufficiently high (Abramitzky, Delavande, and Vasconcelos 2011; Banerjee et al. 2009).

${ }^{3}$ A regression of $A S V O T E^{19 C}$ on city size yields a strongly significant negative coefficient: A one percentage point increase in city size is associated with a $1.6 \%$ decrease in $A_{S V O T E}^{19 C}$ (relative to a standard deviation of 14.4).

${ }^{4}$ The results reported in Table 2 are conditional on city size. When dropping city population from the regressions, the negative relationship with Jewish community size becomes even stronger. In addition, results are very similar when we use the size of Jewish communities in 1925 instead of 1939, i.e., before emigration had diminished the Jewish population in German cities (deportations began on a large scale only after 1939).
} 
direct indicators - the electoral success of anti-Jewish parties, 1890-1912, and medieval pogroms for those locations with a Jewish settlement in the Middle Ages. ${ }^{5}$

[Figure 2 here; Table 2 about here]

In Table 3, we summarize the characteristics of localities by tercile of the share of "mixed Jews” in 1939. The lower the proportion of intermarriages, the smaller the town/city and its Jewish community; the higher the vote share for anti-Semitic parties; and the lower the educational level of the population today. ${ }^{6}$ These empirical regularities suggest that the basic relationship between mixed marriages in the past and attitudes towards intermarriage in Table 1 is not well-specified. Only one of the two determinants of intermarriage - attitudes amongst gentiles towards Jews - will capture the hypothesized relationship.

\section{[Table 3 here]}

In Table 4, we examine this question empirically. Here, we use a two-stage-least-squares approach, predicting the share of mixed offspring in the Jewish population with voting results for the anti-Semitic parties in Germany, 1890-1912. In columns 1 and 2, in the first stage, votes for antiJewish parties are a powerful (negative) predictor of intermarriage. The second stage demonstrates that more intermarriage before 1940, driven by less historical anti-Semitism, is associated with more tolerant attitudes today - both towards marriages with Jews, and with other ethnic minorities. At the same time, we control for Jewish community size, which is strongly positively associated with

\footnotetext{
${ }^{5}$ When using data on pogroms in 1349 , we restrict the sample to cities with documented medieval Jewish settlements. The data are from Voigtländer and Voth (2012).

${ }^{6}$ Note that $A S V O T E^{19 C}$ does not decline continuously with each tercile of intermarriage. This is because the size of Jewish communities is a confounding factor: Intermarriage was higher in cities with less anti-Semitism and with smaller Jewish communities. However, $A S V O T E^{19 C}$ was c.p. higher in smaller cities, with fewer Jews. Once we account for these opposing effects by including city size, Jewish community size, and $A S V O T E^{19 C}$, the results are unambiguous (Table 2).
} 
favorable attitudes towards intermarriage today. This captures the fact that larger cities tend to be more tolerant towards minorities, and also hosted larger Jewish communities before World War II. ${ }^{7}$

In columns 3 and 4 , we show that the second part of the variation in early $20^{\text {th }}$ century intermarriage behavior - driven by the need to marry outside one's own group - is strongly associated with more negative views of intermarriage today. ${ }^{8}$ In other words, where Jewish communities were small and out-marriage was more of a need than a choice, its information value for attitudes amongst gentiles is low. Instead, more intermarriage due to smaller Jewish communities reflects less tolerant attitudes in smaller cities. As it happens, in Germany before 1939, locations with small Jewish communities - mostly rural towns - were more anti-Semitic. Today, these attitudes remain in the smaller towns, giving rise to a paradoxical relationship in the aggregate.

[Table 4 here]

\section{Conclusion}

When does frequent intermarriage indicate tolerance towards a minority? We examine the case of marriages between Jews and gentiles in early $20^{\text {th }}$ century Germany. Places where historical attitudes towards Jews were more negative - as reflected in higher vote shares for anti-Semitic parties in the late $19^{\text {th }}$ and early $20^{\text {th }}$ century - recorded fewer "mixed marriages". At the same time, locations hostile to Jews also had much smaller Jewish communities. For Jews approaching marriage age in these locations, there were few potential mates from within the community available; out-marriage rates were correspondingly higher. We document these patterns using official German statistics on “half Jews”, “quarter Jews”, etc. compiled by the Nazi authorities after 1933.

\footnotetext{
${ }^{7}$ We obtain very similar results when controlling for both present city population and the size of Jewish communities.

${ }^{8}$ We control for ASVOTE ${ }^{19 C}$ in order to isolate the community size effect on intermarriage from the direct effect of historical anti-Semitism. The negative coefficient on ASVOTE $^{19 C}$ in columns 3 and 4 suggests that historical antiSemitism persisted at the local level.
} 
Remarkably, attitudes towards intermarriage are stable over more than half a century - in towns and cities where intermarriage rates between Jews and gentiles were high before 1939 because of positive attitudes amongst the German population, respondents today are much more comfortable with the idea of having a Jewish family member. In contrast, in places where out-marriage rates for Jews were high because the Jewish community was small, attitudes today are also sharply more critical today - not least because the local population was often more hostile, reducing the number of Jews in a location.

The answer to our question - when does intermarriage reflect tolerance - is straightforward: Only the part of the variation driven by attitudes directly is valuable in explaining cultural preferences. The share of the variation reflecting the "tightness" of the marriage market can confound the result; in extreme cases - such as Germany before 1939 - it may even induce an inverse correlation.

\section{References}

Abramitzky, Ran, Adeline Delavande, and Luis Vasconcelos. 2011. “Marrying Up: The Role of Sex Ratio in Assortative Matching.” American Economic Journal: Applied Economics 3 (3): 124 57.

Banerjee, Abhijit, Esther Duflo, Maitreesh Ghatak, and Jeanne Lafortune. 2009. Marry for What: Caste and Mate Selection in Modern India. Working Paper. National Bureau of Economic Research. http://www.nber.org/papers/w14958.

Bisin, Alberto, Giorgio Topa, and Thierry Verdier. 2004. "Religious Intermarriage and Socialization in the United States.” Journal of Political Economy 112 (3) (June 1): 615-664. doi:10.1086/383101.

Blossfeld, Hans-Peter, and A. Timm. 2003. Who Marries Whom? Educational Systems as Marriage Markets in Modern Societies. Springer. 
Burleigh, M., and W. Wippermann. 1991. The Racial State: Germany 1933-1945. Cambridge University Press.

Gabriel, O.W. 2000. “Demokratische Einstellungen in einem Land ohne demokratische Traditionen? Die Unterstützung der Demokratie in den neuen Bundesländern im Ost-West-Vergleich.” Wirklich ein Volk: 41-77.

Meng, Xin, and Robert G. Gregory. 2005. "Intermarriage and the Economic Assimilation of Immigrants.” Journal of Labor Economics 23 (1) (January 1): 135-174. doi:10.1086/425436.

Ritter, Gerhard A., and Merith Niehuss. 1980. "Wahlgeschichtliche Materialien Zur Statistik Des Kaiserreiches 1871-1918 (ZA8348)”. GESIS.

Statistisches Reichsamt. 1944. Die Juden und jüdischen Mischlinge im Deutschen Reich. Vol. 4. Statistik des deutschen Reiches 4 552. Berlin.

Voigtländer, Nico, and Hans-Joachim Voth. 2012. "Persecution Perpetuated: The Medieval Origins of Anti-Semitic Violence in Nazi Germany.” The Quarterly Journal of Economics 127 (3) (August 1): 1339-1392. doi:10.1093/qje/qjs019. 


\section{FIGURES}

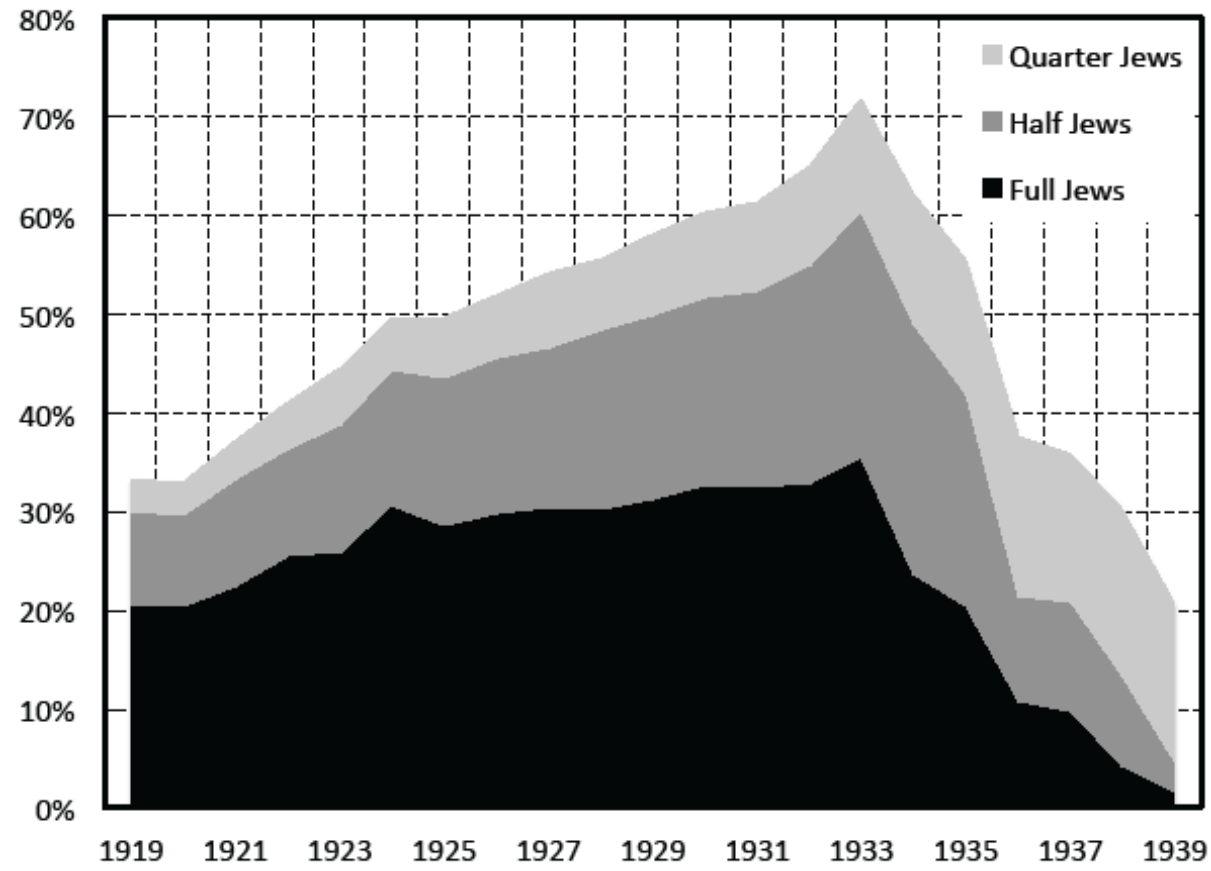

Figure 1: Intermarriage of Jews in Germany, 1919-1939

Note: The figure shows the share of marriages between Jews and gentiles, as a percentage of all marriages involving Jews, in percent.

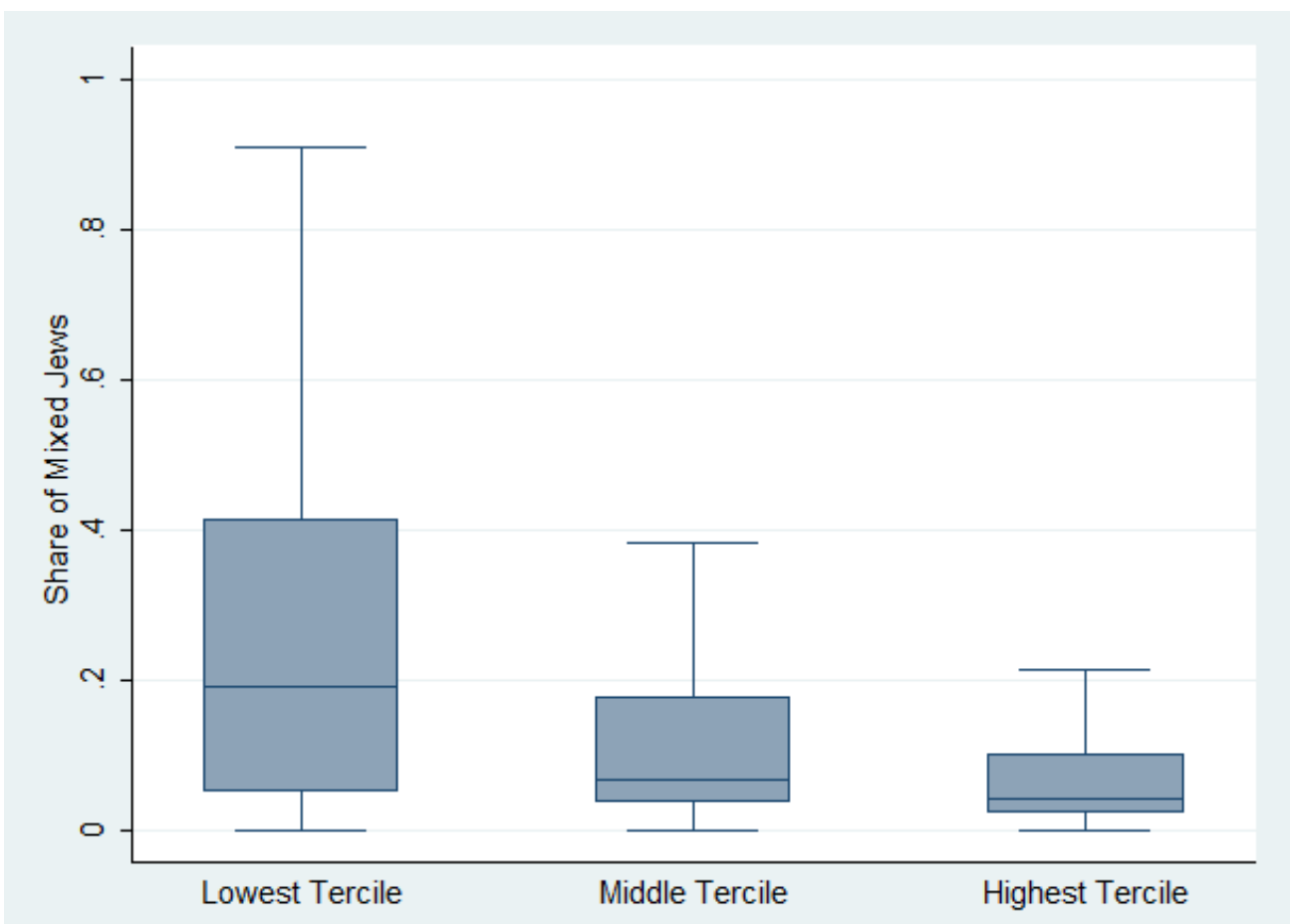

Figure 2: Share of Individuals from Mixed Marriages, by Tercile of Jewish Community Size

Note: "Mixed Jews" are individuals with one or two Jewish grandparents, according to the 1939 German Census. The "whiskers" show the range of the distribution from the $0^{\text {th }}$ to the $100^{\text {th }}$ percentile; the outer frame of the box indicates the $25^{\text {th }}$ and $75^{\text {th }}$ percentiles; and the line in the middle shows the median. 
TABLES

Table 1: Correlation between historical Jewish intermarriage and today’s attitudes

\begin{tabular}{|c|c|c|c|c|}
\hline Dep. Var.: & \multicolumn{2}{|c|}{$\begin{array}{c}\text { Jewish Intermarriage } \\
1996+2006 \\
\end{array}$} & \multicolumn{2}{|c|}{$\begin{array}{l}\text { Intermarriage in General } \\
1996+2006\end{array}$} \\
\hline MixedJew $1^{\text {st }}$ & $\begin{array}{r}-.500 * * \\
(.173)\end{array}$ & & $\begin{array}{r}-.446^{* *} \\
(.129)\end{array}$ & \\
\hline MixedJew $2^{\text {nd }}$ & & $\begin{array}{c}-.405^{* * * *} \\
(.152)\end{array}$ & & $\begin{array}{c}-.381^{* * *} \\
(.118)\end{array}$ \\
\hline CONTROLS & yes & yes & yes & yes \\
\hline $\begin{array}{l}N \\
R^{2}\end{array}$ & $\begin{array}{l}4,735 \\
.038\end{array}$ & $\begin{array}{l}4,538 \\
.037\end{array}$ & $\begin{array}{l}4,715 \\
.065\end{array}$ & $\begin{array}{c}4,520 \\
.064\end{array}$ \\
\hline
\end{tabular}

Notes: Standard errors in parentheses. ${ }^{*} p<0.1,{ }^{* *} p<0.05$, *** $p<0.01$. The dependent variable in columns 1 and 2 reflects attitudes towards intermarriage with Jews in 264 German municipalities in 1996 and 2006. The variable is the answer to the question "How agreeable or disagreeable would it be for you if a Jew married into your family?", on a scale from 1("very disagreeable") to 7 ("very agreeable"). MixedJew $1^{\text {st }}$ is the percentage of "mixed Jews" in 1939 of first degree, with two Jewish grandparents. MixedJew $2^{\text {nd }}$ is the percentage of "mixed Jews" of first or second degree, with one or two Jewish grandparents. The dependent variable in columns 3 and 4 reflects attitudes towards intermarriage in general, using the average response to same question for Jews, Turks, Italians, ethnic German emigrants, and asylum seekers. CONTROLS comprise dummies for high school and university degrees, age, age ${ }^{2}$, and a dummy for the sample year 2006. All regressions include only subjects with German nationality and at least two generations of German ancestors.

Table 2: Historical determinants of Jewish intermarriage

\begin{tabular}{lcccc}
\hline \multicolumn{1}{c}{ Dep. Variable } & \multicolumn{1}{c}{$(1)$} & $(2)$ & $(3)$ & $(4)$ \\
\hline $\ln$ (Size Jewish & $-.0514^{* * *}$ & $-.0763^{* * *}$ & $-.0763^{* * *}$ & $-.0963^{* * *}$ \\
Comm. 39) & $(.00703)$ & $(.0132)$ & $(.00897)$ & $(.0129)$ \\
$\ln \left(\right.$ Pop'33) $\left.^{\prime}\right)$ & $.0393^{* * *}$ & $.0515^{* * *}$ & $.0501^{* * *}$ & $.0659^{* * *}$ \\
& $(.00362)$ & $(.00680)$ & $(.00449)$ & $(.00702)$ \\
ASVOTE $^{19 C}$ & $-.102^{* * *}$ & & $-.116^{* * *}$ & \\
& $(.0276)$ & & $(.0440)$ & \\
POG $^{1349}$ & & $-.0368^{*}$ & & $-.0531^{* *}$ \\
& & $(.0200)$ & & $(.0236)$ \\
\hline$N$ & 758 & 322 & 759 & 324 \\
$R^{2}$ & .309 & .296 & .337 & .357 \\
\hline
\end{tabular}

Notes: Standard errors in parentheses, clustered at the county level. ${ }^{*} p<0.1,{ }^{* *} p<0.05$, ${ }^{* * *} p<0.01$. MixedJew ${ }^{\text {st }}$ is the percentage of "mixed Jews" of first degree, with two Jewish grandparents. MixedJew $2^{\text {nd }}$ is the percentage of "mixed Jews" of first or second degree, with one or two Jewish grandparents. ASVOTE ${ }^{19 C}$ is the average vote for anti-Semitic parties between 1890 and 1912. $P O G^{1349}$ takes the value 1 if a pogrom against the local Jewish community occurred in the years 1348-50, and 0 otherwise. 
Table 3: City characteristics by tercile of historical intermarriage

\begin{tabular}{|c|c|c|c|c|c|c|c|}
\hline \multicolumn{5}{|c|}{--- Historical --- } & \multicolumn{3}{|c|}{--- Today--- } \\
\hline & ew $2^{\text {nd }}$ & Pop’33 & Size Jew. & ASVOTE $^{19 C}$ & \%High & \% Uni- & Jewish \\
\hline Tercile & Value & & commun. & & School & versity & Intermarr. \\
\hline 1 & .169 & 141,940 & 2,270 & .044 & .184 & .141 & 4.04 \\
\hline 2 & .411 & 105,611 & 609 & .021 & .171 & .129 & 4.00 \\
\hline 3 & .694 & 15,516 & 61 & .030 & .143 & .122 & 3.89 \\
\hline
\end{tabular}

MixedJew $2^{\text {nd }}$ is the percentage of "mixed Jews" of first or second degree in 1939, with one or two Jewish grandparents. ASVOTE $^{19 C}$ is the average vote for anti-Semitic parties between 1890 and 1912 .The size of the Jewish community refers to the year 1939. "Jewish Intermarr." summarizes attitudes towards intermarriage with Jews in 264 German municipalities in 1996 and 2006. The variable is the answer to the question "How agreeable or disagreeable would it be for you if a Jew married into your family?”, on a scale from 1(“very disagreeable”) to 7 (“very agreeable”).

Table 4: Historical intermarriage and anti-Semitic sentiments

Dep. Var.: Attitudes towards Jewish Intermarriage in 1996-2006

\begin{tabular}{|c|c|c|c|c|}
\hline & $(1)$ & $(2)$ & $(3)$ & $(4)$ \\
\hline \multicolumn{5}{|c|}{ Second Stage: Use MixedJew predicted by: } \\
\hline & \multicolumn{2}{|c|}{ 19C anti-Semitism } & \multicolumn{2}{|c|}{ Jewish community size in ' 39} \\
\hline Predicted MixedJew $1^{\text {st }}$ & $\begin{array}{l}4.046 * * \\
(2.047)\end{array}$ & & $\begin{array}{c}-1.743 * * * \\
(0.395)\end{array}$ & \\
\hline Predicted MixedJew $2^{\text {nd }}$ & & $\begin{array}{c}3.217 * * \\
(1.495)\end{array}$ & & $\begin{array}{c}-1.323 * * * \\
(0.275)\end{array}$ \\
\hline $\begin{array}{l}\ln (\text { Size Jewish } \\
\text { Community‘39) }\end{array}$ & $\begin{array}{l}.203^{* *} \\
(.0836)\end{array}$ & $\begin{array}{l}.215^{* * *} \\
(.0829)\end{array}$ & & \\
\hline ASVOTE $^{19 C}$ & & & $\begin{array}{c}-1.482 * * * \\
(0.486)\end{array}$ & $\begin{array}{c}-1.446 * * * \\
(0.480)\end{array}$ \\
\hline CONTROLS & yes & yes & yes & yes \\
\hline$N$ & 4,524 & 4,538 & 4,524 & 4,538 \\
\hline \multicolumn{5}{|c|}{ First Stage: Predicting MixedJew } \\
\hline \multicolumn{5}{|l|}{ “Instrument”: } \\
\hline ASVOTE $^{19 C}$ & $\begin{array}{l}-.254 * \\
(.148)\end{array}$ & $\begin{array}{l}-.312 * \\
(.179)\end{array}$ & & \\
\hline $\begin{array}{l}\ln (\text { Size Jewish } \\
\text { Community‘39) }\end{array}$ & & & $\begin{array}{c}-.0348 * * * \\
(.00786)\end{array}$ & $\begin{array}{c}-.0471 * * * \\
(.00949)\end{array}$ \\
\hline$R^{2}$ & .168 & .223 & .139 & .188 \\
\hline
\end{tabular}

Notes: Standard errors in parentheses, clustered at the municipality level. $* p<0.1,{ }^{* *} p<0.05, * * * p<0.01$. The dependent variable reflects attitudes towards intermarriage with Jews in 264 German municipalities in 1996 and 2006. The variable is the answer to the question "How agreeable or disagreeable would it be for you if a Jew married into your family?", on a scale from 1 ("very unpleasant") to 7 ("very pleasant"). MixedJew 1 st is the percentage of "mixed Jews" of first degree, with two Jewish grandparents. MixedJew $2^{\text {nd }}$ is the percentage of "mixed Jews" of first or second degree, with one or two Jewish grandparents. CONTROLS comprise dummies for high school and university degrees, age, age ${ }^{2}$, and a dummy for the sample year 2006. The first stage regressions also include all controls used in the second stage. All regressions include only subjects with German nationality and at least two generations of German ancestors. 